\title{
Dendritic Cells and Programmed Death-1 Blockade: A Joint Venture to Combat Cancer
}

\author{
Maarten Versteven ${ }^{1 *}$, Johan M. J. Van den Bergh ${ }^{1 \dagger}$, Elly Marcq ${ }^{2}$, Evelien L. J. Smits ${ }^{1,2,3}$, \\ Viggo F. I. Van Tendeloo', Willemijn Hobo ${ }^{4}$ and Eva Lion ${ }^{1,3}$ \\ ${ }^{1}$ Laboratory of Experimental Hematology, Faculty of Medicine and Health Sciences, Vaccine and Infectious Disease Institute \\ NAXINFECTIO), University of Antwerp, Antwerp, Belgium, ${ }^{2}$ Center for Oncological Research Antwerp, Faculty of Medicine \\ and Health Sciences, University of Antwerp, Antwerp, Belgium, ${ }^{3}$ Center for Cell Therapy and Regenerative Medicine, \\ Antwerp University Hospital, Antwerp, Belgium, ${ }^{4}$ Laboratory of Hematology, Department of Laboratory Medicine, Radboud \\ Institute for Molecular Life Sciences, Radboud University Medical Center, Nijmegen, Netherlands
}

\section{OPEN ACCESS}

Edited by:

Piergiuseppe De Berardinis, Istituto di Biochimica delle

Proteine (CNR), Italy

Reviewed by:

Daniela Fenoglio,

Università di Genova, Italy

Dalil Hannani,

UMR5525 Techniques de l'Ingénierie Médicale et de la

Complexité Informatique, Mathématiques et Applications, Grenoble (TIMC-IMAG), France

*Correspondence:

Maarten Versteven maarten.versteven@uantwerpen.be

tThese authors have contributed equally to this work.

Specialty section:

This article was submitted to Molecular Innate Immunity, a section of the journal Frontiers in Immunology

Received: 15 January 2018 Accepted: 13 February 2018

Published: 01 March 2018

Citation:

Versteven M, Van den Bergh JMJ, Marcq E, Smits ELJ,

Van Tendeloo VFI, Hobo W and Lion E (2018) Dendritic Cells and Programmed Death-1 Blockade: A Joint Venture to Combat Cancer.

Front. Immunol. 9:394. doi: 10.3389/fimmu.2018.00394
Two decades of clinical cancer research with dendritic cell (DC)-based vaccination have proved that this type of personalized medicine is safe and has the capacity to improve survival, but monotherapy is unlikely to cure the cancer. Designed to empower the patient's antitumor immunity, huge research efforts are set to improve the efficacy of next-generation DC vaccines and to find synergistic combinations with existing cancer therapies. Immune checkpoint approaches, aiming to breach immune suppression and evasion to reinforce antitumor immunity, have been a revelation in the immunotherapy field. Early success of therapeutic antibodies blocking the programmed death-1 (PD-1) pathway has sparked the development of novel inhibitors and combination therapies. Hence, merging immunoregulatory tumor-specific DC strategies with PD-1-targeted approaches is a promising path to explore. In this review, we focus on the role of PD-1signaling in DC-mediated antitumor immunity. In the quest of exploiting the full potential of DC therapy, different strategies to leverage DC immunopotency by impeding PD-1mediated immune regulation are discussed, including the most advanced research on targeted therapeutic antibodies, lessons learned from chemotherapy-induced immune activation, and more recent developments with soluble molecules and gene-silencing techniques. An overview of DC/PD-1 immunotherapy combinations that are currently under preclinical and clinical investigation substantiates the clinical potential of such combination strategies.

Keywords: dendritic cell, programmed death-1, cancer immunotherapy, combination therapy, programmed death ligand $1 / 2$

\section{INTRODUCTION}

Dendritic cells (DCs) are key antigen-presenting cells capable of presenting tumor antigens to Tlymphocytes (1) and promoting innate immunity via, e.g., natural killer (NK) cells (2) and $\gamma \delta \mathrm{T}$ cells (3). To obtain and engineer DCs for therapeutic approaches, they can be generated ex vivo from multiple sources such as monocytes [monocyte-derived DCs (moDCs)] and CD34 ${ }^{+}$hematopoietic progenitor cells, or they can be enriched from peripheral and cord blood (4-7). Exploiting their 
antigen-specific and immunoregulatory qualities, DCs can be furnished with tumor antigens and other targeted molecules via different techniques (7-9). More than two decades after the first implementation of DCs as an immunotherapy to treat cancer (10), it can be ascertained that DC-based vaccination is safe, well tolerated, and capable of inducing antitumoral immune responses. Objective clinical responses, however, are amenable to substantial improvement (11). To date, scientists believe that the full potential of DC-based immunotherapy has not yet been reached (11-13). This is evidenced by the profound and multidimensional exploration of ways to invigorate the immunotherapeutic potential of DCs, both at the level of DC vaccine engineering and combining DC therapy with other synergistic antitumor (immuno)therapies (14-20). Core objectives of this common quest are to improve DC immunopotency to promote cytotoxic and long-lasting antitumor immunity and to overcome the tumor-mediated immunosuppressive environment $(9,20)$. In relation to this, interfering with immune checkpoint inhibitory pathways has been on the rise. Since its second-place ranking as a potential target for immunotherapy at the Immunotherapy Agent Workshop of the National Cancer Institute in 2007 research on the inhibitory checkpoint programmed death-1 (PD-1)/programmed death ligand (PDL) pathway has boosted massively. Due to superior antitumor effects of anti-PD-1- and anti-PD-L1-blocking antibodies, these molecules even climbed to the first position as potential targets for immunotherapy at the 29th Annual meeting of the Society for Immunotherapy of Cancer in 2015 (21). Next to exploiting the systemic monoclonal antibody $(\mathrm{mAB})$ strategy, other promising PD-1-/PD-L-targeted approaches are under development. As acknowledged for DC-based vaccination, combination strategies of PD-1-targeted inhibitors with other immune (checkpoint) modulators, cell vaccines, or standard-of-care therapies will likely hold the future (22). In this review, we discuss the role of the PD-1/PD-L pathway in DC-mediated antitumor immunity and the progress of emerging strategies combining DC-based therapy with PD-1/PD-L pathway interference.

\section{PD-1/PD-L IN HEALTH AND DISEASE}

The PD-1/PD-L axis is one of the most studied pathways to gain understanding of immunoregulatory signals delivered by immune checkpoint receptor/ligand interaction the past few years $(23,24)$. Originally discovered as a mechanism of the organism to protect itself against $\mathrm{T}$ cell reactions toward selfantigens, interaction of PD-1 with one of its ligands (PD-L1 or PD-L2) can induce peripheral tolerance by limiting $\mathrm{T}$ cell activity, contributing to protection against tissue damage in case of an inflammatory response (25), prevention of autoimmune diabetes (26), or promotion of the fetal-maternal tolerance (27). Infected and malignant cells that evade immune surveillance have been ascribed to employ the inhibitory PD-1/PD-L pathway (24). Indispensable in healthy immune responses (28, $29)$, overexpression or induction of PD-1 and its ligands PD-L1 and PD-L2 on both immune and target cells, has been associated with immune deficiency, such as exhausted T cells, dysfunctional NK cells, expanded functional regulatory $\mathrm{T}$ (Treg) cells, and immune evasion and suppression $(30,31)$. PD-L expression can also be indispensable for the establishment of $\mathrm{T}$ cell immunity in other settings $(28,29)$. This ambiguity could be explained by findings that PD-L2 also possesses a costimulatory role $(32,33)$, possibly through interaction with repulsive guidance molecule $b$ (34). Arising from either intrinsic or adaptive immune resistance (35), PD-1 and PD-L1 surface expression or secretion in different malignancies has been mostly related to poor prognosis (36-42), although discordant data have been reported $(43,44)$, reflecting the need to improve our understanding of the host immune system and disease-specific microenvironment.

Inhibitory PD-1/PD-L signaling not only occurs between immune cells interacting with malignant cells, but is also effective between different immune cell types shaping the tumor immune environment. This provides a strong impetus to target this inhibitory axis to breach immune inhibition and promote durable immunity. In various solid and hematological tumors, blockade of the PD-1/PD-L1 pathway has proven to reverse this immune inhibition by restoring both antitumor function and number of tumor-infiltrating $\mathrm{CD}^{+}$effector $\mathrm{T}$ cells, resulting in reduced tumor size and increased overall survival (45-49). While PD-1-/PD-L-targeted research predominantly focuses on effector T cells, interest in other cell types is growing. A study in metastatic melanoma patients showed that, in addition to CD8 ${ }^{+}$ T cells, tumor-infiltrating B cells and myeloid-derived suppressor cells (MDSCs) were increased by PD-1 therapy (50). With regard to innate immunity, it has been evidenced that also NK cells are negatively regulated by PD-1 signaling during chronic infections (Mycobacterium tuberculosis and HIV-1) $(51,52)$ and in cancer (multiple myeloma, glioblastoma multiforme, ovarian carcinoma, digestive cancers) (53-59), directly relating to NK cell cytotoxic and regulatory dysfunction, immune suppression, and poor prognosis. As for T cells, blockade of this inhibitory pathway by means of $\mathrm{mABs}$ could restore dampened NK cell functions, at the level of both interferon (IFN) $-\gamma$ response (52) and cytotoxic capacity (57). In addition, antitumor immunity mediated by invariant NK T (iNKT) cells was also shown to be improved by blockade of the PD-1/PD-L pathway $(60,61)$. Expression of PD-1 is also demonstrated on $\gamma \delta$ T cells (62) and resulted in $\gamma \delta$ $\mathrm{T}$ cell exhaustion that could be overcome by administration of a blocking anti-PD-L1 antibody $(63,64)$. A subset of $\gamma \delta$ T cells also expresses $\mathrm{PD}-\mathrm{L} 1$ conferring them with tumor-promoting characteristics by inhibiting $\alpha \beta$ T cells (65). Therefore, PD-L1-blocking antibodies could also restore antitumor immunity by inhibiting PD-1/PD-L1 interactions between $\gamma \delta$ and $\alpha \beta$ T cells. With regard to immunoregulatory cells, $\mathrm{PD}-1$ is also highly expressed on Treg cells (66). As shown by Sauer et al. (67) and Francisco et al. (68), interaction between PD-1 and its ligands blocks the Akt/mTOR pathway leading to an increased FoxP3 expression, resulting in Treg cell differentiation and maintenance. Furthermore, blocking the PD-1 pathway combined with antitumor vaccination showed a significant decrease in the number of intratumoral Treg cells and reduced tumor growth (69). In addition to Treg cells, a role for the PD-1/PD-L pathway has been put forward for other regulatory cells including tumor-associated macrophages (TAMs), MDSCs, and mucosal-associated invariant T (MAIT) cells (61, 70-75). While research into the effect of $\mathrm{PD}-1 / \mathrm{PD}-\mathrm{L}$ blockade in these cells is limited, preclinical anti-PD-1 therapy has been shown to 
reduce the number of immune suppressive TAMs and MDSCs (73) and was able to increase the IFN- $\gamma$ production by MAIT cells (71), indicating the valuable effect of PD-1/PD-L blockade on immune cells beyond the immune-activating $\mathrm{CD}^{+} \mathrm{CTLs}$.

\section{THE ROLE OF PD-1/PD-L IN DC- MEDIATED ANTITUMOR IMMUNITY}

As orchestrators of the immune system bridging innate and adaptive immunity, DCs are key players in directing antitumor immunity. Capable of expressing both the PD-1 receptor and its ligands, DCs can virtually interact with any PD-1 and PD-Lpositive cell (Figure 1). In this context, the most acknowledged interaction is between DCs and T cells. PD-L surface expression on DCs [myeloid DC (mDC), plasmacytoid DC (pDC), and in vitro generated vaccine $\mathrm{DC}$ ] is highest upon maturation with pro-inflammatory cytokines, Toll-like receptor (TLR) ligands, or (parts of) bacterial strains, often used to enhance the expression of costimulatory molecules on DCs (76-78). This PD-L surface expression has been demonstrated to suppress $\mathrm{CD}^{+}$and $\mathrm{CD}^{+}$ $\mathrm{T}$ cell activity in various disease models, such as tuberculosis (79-81), HIV (82), and cancer (76, 83-88). Comparably, PD-1 expression on tumor-infiltrating $\mathrm{mDCs}$ has also been shown to suppress $\mathrm{CD}^{+} \mathrm{T}$ cell activity and decrease $\mathrm{T}$ cell infiltration in mouse models for advanced ovarian cancer (89) and hepatocellular carcinoma (90). In addition to suppression of immune activation, DC PD-L expression was also shown to be involved in the promotion of $\mathrm{CD}^{+} \mathrm{CD} 25^{+} \mathrm{FoxP} 3^{+}$Treg cell expansion and function (68). Tumor growth factor-beta in the tumor microenvironment promotes PD-L1 expression on DCs, further maintaining Treg cell populations $(87,91)$ and de novo generation of Treg cells (92) in favor of the immunosuppressive tumor microenvironment (84).

The role of PD-1/PD-L signaling in the crosstalk between DCs and NK cells remains largely unexplored. It has been shown that disruption of the PD-1/PD-L pathway is able to restore NK cell functions, mostly, but not exclusively in multiple myeloma (53, $55,57,93)$. Only few studies suggest a role of this pathway in DC-NK cell crosstalk and controversy remains. Ray et al. (57) demonstrated that NK cell function was abrogated by PD-L1 interactions on pDCs and PD-1 on NK cells and that NK cell functions could be restored by anti-PD-L1 treatment. On the other hand, in a preclinical mouse model, the expression of PD-L on NK cells was demonstrated to negatively regulate DC activity via interaction with PD-1 on DCs (94). To gain more conclusive insights in the contribution of PD-1/PD-L interactions in the crosstalk between DCs and NK cells, more research is warranted. Similar to DC-NK cell crosstalk, little is known about the role of PD-1 signaling in DC- $\gamma \delta$ T cell crosstalk $(3,95)$ and how PD-1/ PD-L blockade in combination with DC-based immunotherapies can further empower $\gamma \delta$ T cells with antitumor capacities. Other innate immune cells that are able to crosstalk with DCs include iNKT cells, MAIT cells, and MDSCs (96-100). Blockade of PD-1/ PD-L interactions between DCs and iNKT cells were shown to increase activation and release of T helper 1 cytokines by the latter resulting in the activation of NK cells and amplified antitumor responses $(60,101)$. Research on PD-1/PD-L interactions between DCs and MAIT cells or MDSCs is lacking.

Ligation of PD-1 to PD-L1/2 can also exert intrinsic effects on DCs by reverse signaling. Kuipers et al. (102) reported decreased expression of maturation markers in $\mathrm{PD}-\mathrm{L}^{+} \mathrm{DCs}$ and increased interleukin (IL)-10 production upon treatment with soluble $\mathrm{PD}-1$ (sPD-1), suggesting that through reciprocal signaling a suppressive DC phenotype is attained. In another study, upregulation of PD-1 on DCs was found to be a consequence of DC maturation, especially after TLR-mediated DC activation. Blocking PD-1 during DC maturation resulted in enhanced DC survival and increased immunostimulatory properties (103). In both studies, interference with the PD-1/PD-L pathway increased the immunostimulatory properties of the DCs toward T cell activation.

The interplay of PD-1 and PD-L in DC crosstalk with (virtually all) activating and regulatory adaptive and innate immune cells impacts the productivity of antitumor immunity (Figure 1). Other than monitoring PD-L expression on tumor cells, it has been suggested that monitoring PD-L expression on infiltrating myeloid cells is more predictive for response to blockade of PD-1 signaling (104). Building on the successes of DC-based therapy (11) and PD-1-blocking strategies (105), the exploration of its combinatorial therapeutic use is rationalized to empower the clinical response rates and efficacy of these targeted approaches $(7,16)$.

\section{STRATEGIES TO LEVERAGE DC IMMUNOPOTENCY BY INTERCEDING PD-1/PD-L SIGNALING}

It is generally agreed that the therapeutic potential of DC-based immunotherapy could be improved by tackling the immunosuppressive tumor microenvironment that contributes to ineffective or suboptimal responses $(106,107)$. Employing intrinsic and adaptive immune resistance mechanisms, PD-1 is a top-ranked checkpoint contributor to blunting immune responses. In a comprehensive review on the molecular and immunological hallmarks and prerequisites for next-generation DC vaccines, Garg et al. (20) discourses its combinatorial use with immune checkpoint inhibitors to enforce efficient antitumor activity. Based on the expression pattern of PD-1 and PD-L on immune cells and cellular contacts between DC and a myriad of immune effector and regulatory cells, blocking PD-1/PD-L interactions will likely impede tumor cell-mediated immune suppression, enhance $\mathrm{T}$ cell and NK cell activation and effector functions, and inhibit conversion or activation of Treg cells. However, these actions depend also on the way of implementation of PD-1/PD-L blockade with DC vaccination. Here, we elaborate on the currently applicable strategies (Figure 2) and clinical trials (Tables 1 and 2) that particularly interfere with the $\mathrm{PD}-1 / \mathrm{PD}-\mathrm{L}$ pathway in the context of DC-based immunotherapies.

\section{Systemic Receptor-Ligand Blockade}

The use of mABs that block immune checkpoints, particularly cytotoxic T lymphocyte antigen-4 (CTLA-4), PD-1, and PD-L1, has made a profound impact in the field of cancer immunotherapy 


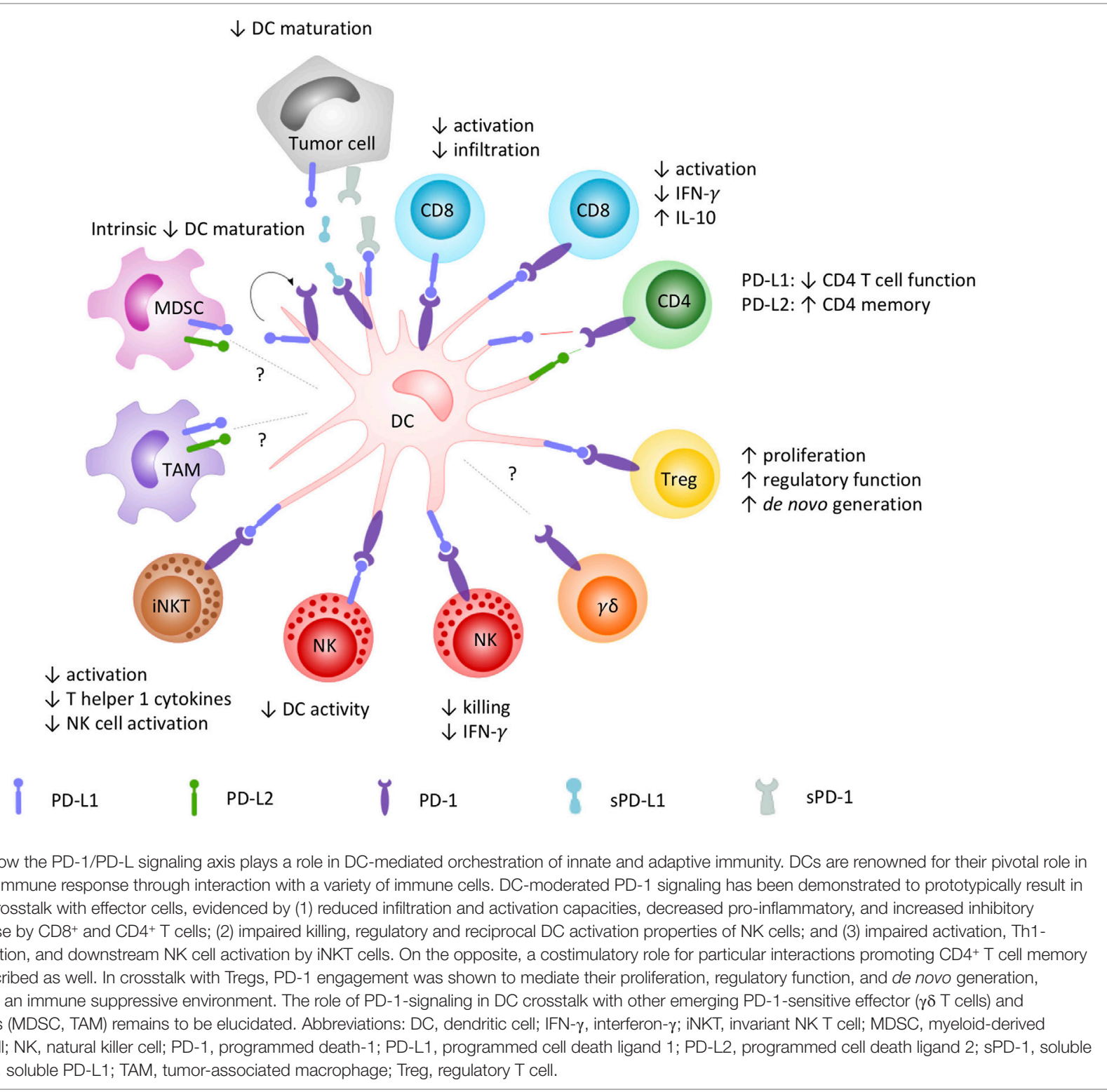

(108). As of 2011, treatment of several malignancies with antiCTLA-4- (ipilimumab), anti-PD-1- (nivolumab and pembrolizumab), and anti-PD-L1- (atezolizumab, durvalumab, and avelumab) blocking antibodies has been approved by the US FDA and EMA and a series of new inhibitors is being assessed in late stage clinical trials (105). With the experience that anti-CTLA-4 therapy comes with higher toxicity and lower response rates (16, $109,110)$, the focus of research is propelling toward the PD-1/ PD-L pathway as evidenced by the myriad of publications on fundamental, preclinical, and clinical PD-1/PD-L research and on its prognostic and predictive biomarker value. As an example, one of the latest developments is to extend the systemic antibodyblocking function with antibody-dependent cellular cytotoxicity (ADCC) properties. The majority of $\mathrm{mABs}$ bear a mutation in their Fc portion, making target cells insensitive to ADCC mediated through the Fc $\gamma$ RIIIa on NK cells. Keeping the Fc part not mutated, avelumab resulted in ADCC-mediated clearance of PD-L1+ tumor cells (111).

In combination with DC vaccination, systemic blockade with anti-PD-1 mABs $(112,113)$ or anti-PD-L mABs (114-116) resulted in increased activation of cytotoxic $\mathrm{CD}^{+} \mathrm{T}$ cells and decreased Treg cell numbers (112) and showed better therapeutic efficacy compared with either monotherapy by preventing tumor growth and prolonging survival in tumor-bearing mice [glioblastoma (113), breast cancer (114), and melanoma (116)]. Recent studies evaluated the effect of different immune checkpoint inhibitors on human $\mathrm{T}$ cell responses after co-culture with allogeneic moDCs. In this setting, PD-1 and B and T lymphocyte attenuator (BTLA)-blocking antibodies could increase IFN- $\gamma$ production and proliferation by $\mathrm{T}$ cells. Combined with anti-PD-1, other emerging immune checkpoint inhibitors such as anti-T cell immunoglobulin and mucin-domain containing-3 (TIM-3), 


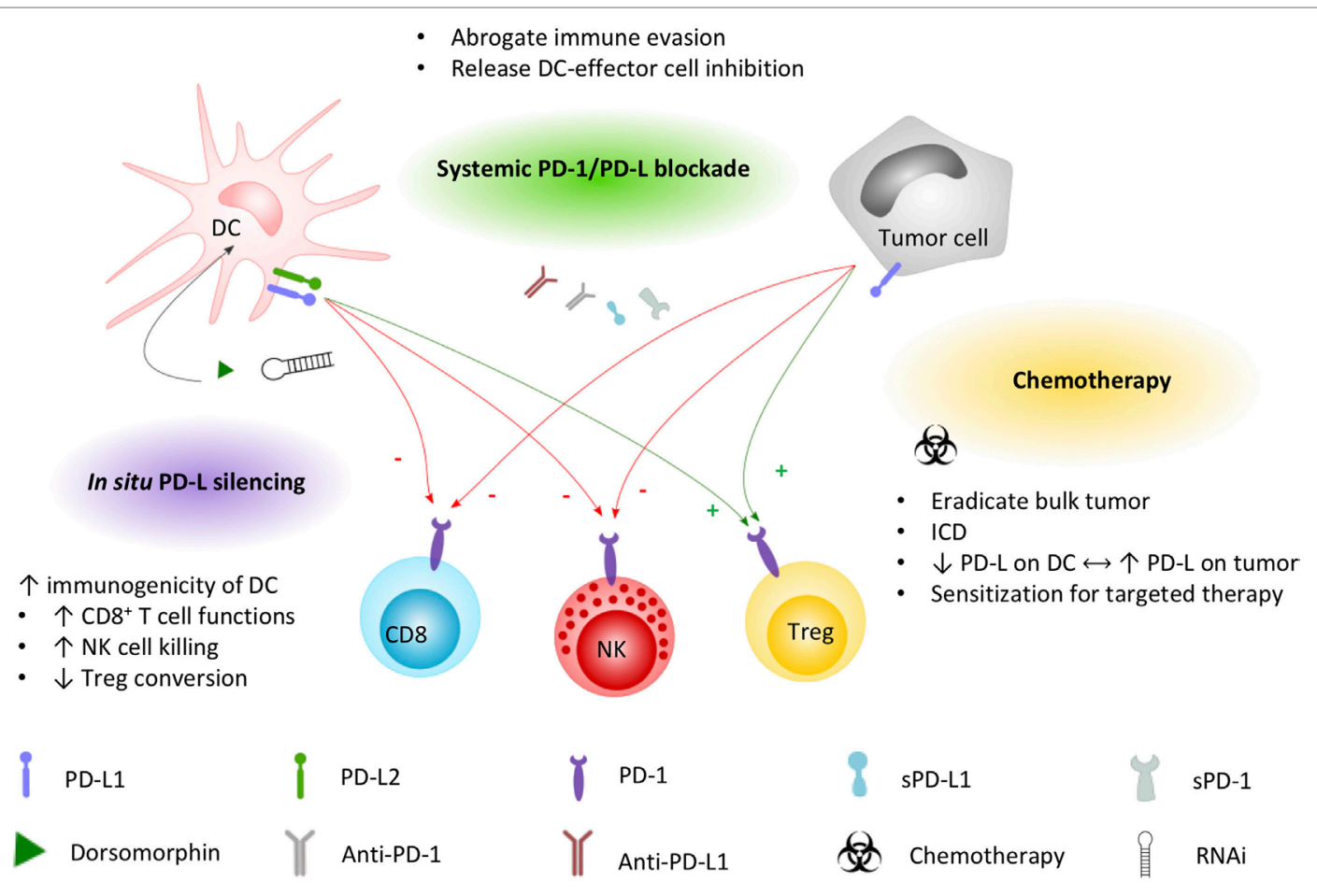

FIGURE 2 | Applied strategies to leverage DC immunopotency by interfering PD-1/PD-L signaling. DC and tumor cell PD-L1 and/or PD-L2 expression exerts direct inhibitory effects (-, red arrows) on CD8 ${ }^{+} \mathrm{T}$ cells and NK cells, while promoting (+, green arrows) regulatory $\mathrm{T}$ cell functions. Current strategies to increase the immunogenicity of DC vaccines by interfering the PD-1/PD-L signaling axis include combined systemic blockade by means of PD-L1-blocking moieties.

Chemotherapy triggers different mechanisms that can promote DC vaccine efficacy, including the induction of immunogenic cell death favorable for DC activation. Exploiting the PD-1 pathway, platinum-based chemotherapeutics have been demonstrated to lower PD-L expression on DCs while increasing tumor cell PD-L expression, sensitizing the tumor for systemic blockade approaches. In situ engineering of DC vaccines by silencing PD-L with the small molecule dorsomorphin or RNAi constructs was demonstrated to successfully improve the immunopotency of DC vaccines. Abbreviations: DC, dendritic cell; ICD, immunogenic cell death; NK, natural killer cell; PD-1, programmed death-1; PD-L1, programmed cell death ligand 1; PD-L2, programmed cell death ligand 2; RNAi, RNA interference; SPD-1, soluble PD-1; sPD-L1, soluble PD-L1; Treg, regulatory T cell.

anti-lymphocyte activating gene-3 (LAG-3), anti-CTLA-4, and anti-BTLA were able to further increase the IFN- $\gamma$-producing and proliferative capacity of T cells, while ineffective on their own $(117,118)$. These findings further underscore the strength of the PD-1-/PD-L-signaling axis relative to other immune checkpoint pathways.

Over the past 8 years, a select number of phase I/II clinical trials combining DC vaccination with anti-PD-1 or anti-PD-L1 antibodies in a range of malignancies have been initiated and are currently all ongoing (Table 1). With the first clinical results expected in the near future, the challenges of conceptualization of such combination therapy are already subject of discussion (20). The growing portfolio of both next-generation DC vaccines and available PD-1 and PD-L targeting mABs makes the possible treatment regimens infinite. Moreover, knowledge is growing that tumors are differentially sensitive to either DC therapy or antibody-mediated checkpoint blockade, either intrinsically or dependent on the stage of the disease. While DC-mediated therapy is consistently proven safe (7), systemic mAB therapy has to deal with several immune-related adverse effects such as skin and mucosal irritation, diarrhea, hepatotoxicity, and endocrinopathy $(110,119)$. Today, we are learning how to recognize and manage immune-related adverse events and toxicities and gaining knowledge on which therapeutic combinations could be applied best at what time point $(120,121)$. As an alternative to human(ized) $\mathrm{mABs}$, different blocking moieties with advanced target specificity and affinity and reduced toxicity profiles are under investigation, including chimeric fusion proteins (AMP224, extracellular domain of PD-L2, and an Fc portion of IgG) and nanotechnologies [nanoparticles (122) and nanobodies ((123), Theravectys, Ablynx)]. Although research in this area is limited, these alternative blockers have interesting features because of their size, stability, and pharmacodynamical properties (124), which might pave the way for implementation in combination therapy with DCs.

\section{Soluble PD-(L)1}

Comparable to the systemic antibody approach is the use of sPD-1 receptor, which only contains the extracellular domain of the PD-1 molecule and can ligate to PD-Ls, making them inaccessible for interaction with PD-1 molecules on immune effector cells. Binding of sPD-1 to surface PD-L on DCs was demonstrated to enhance proliferation of lymphocytes in vitro. In addition, after administration of a vector encoding for SPD-1, tumor growth was inhibited or delayed in a murine model of hepatocarcinoma (125). Similar results were found by Song et al. (126) who additionally 
TABLE 1 | Active clinical trials combining DC-based anticancer immunotherapy with PD-1/PD-L-targeted therapy (clinicaltrials.gov, January 14, 2018),

Intervention Therapy schedule

Type of DC vaccin

\section{PD-1-/PD-L-targeted Type of DC vaccine}

\section{therapy}

\begin{tabular}{|c|c|c|c|c|c|c|c|c|}
\hline \multirow[t]{3}{*}{$\begin{array}{l}\text { Anti-PD-1 Ab } \\
\text { (nivolumab) }\end{array}$} & $\begin{array}{l}\text { Autologous DC loaded with } \\
\text { CMV pp65 mRNA }\end{array}$ & $\begin{array}{l}\text { Neoadjuvant }+ \text { adjuvant DC vaccination with } \\
\text { anti-PD-1 therapy }\end{array}$ & $\begin{array}{l}\text { Without neoadjuvant DC } \\
\text { vaccination }\end{array}$ & $\begin{array}{l}\text { Recurrent brain } \\
\text { tumors }\end{array}$ & I & 7 & NCT02529072 & $\begin{array}{l}\text { Active, not } \\
\text { recruiting }\end{array}$ \\
\hline & $\begin{array}{l}\text { Autologous DC loaded with } \\
\text { NY-ESO-1 peptide }\end{array}$ & $\begin{array}{l}\text { Therapy cycles of cyclophosphamide, TCR- } \\
\text { transduced PBMC, anti-PD-1 therapy, DC } \\
\text { vaccination, and rhIL-2 }\end{array}$ & Single group & $\begin{array}{l}\text { NY-ESO-1+ solid } \\
\text { tumors }\end{array}$ & 1 & 12 & NCT02775292 & Recruiting \\
\hline & $\begin{array}{l}\text { Autologous DC loaded with } \\
\text { autologous tumor lysate }\end{array}$ & $\begin{array}{l}\text { Therapy cycles of i.d. DC vaccination with } \\
\text { anti-PD-1 therapy }\end{array}$ & DC therapy alone & $\begin{array}{l}\text { Recurrent } \\
\text { glioblastoma }\end{array}$ & $\|$ & 30 & NCT03014804 & $\begin{array}{l}\text { Not yet } \\
\text { recruiting }\end{array}$ \\
\hline \multirow[t]{5}{*}{$\begin{array}{l}\text { Anti-PD-1 Ab } \\
\text { (pembrolizumab) }\end{array}$} & $\begin{array}{l}\text { Autologous DC loaded with } \\
\text { peptide }\end{array}$ & Anti-PD-1 SoC post-DC therapy & Single group & Advanced melanoma & 1 & 12 & NCT03092453 & Recruiting \\
\hline & $\begin{array}{l}\text { Autologous DC loaded with } \\
\text { autologous tumor antigens }\end{array}$ & $\begin{array}{l}\text { Therapy cycles of anti-PD-1 and cryosurgery } \\
\text { plus i.t. DC vaccination }\end{array}$ & Single group & $\begin{array}{l}\text { Non-Hodgkin } \\
\text { lymphoma }\end{array}$ & |/II & 44 & NCT03035331 & Recruiting \\
\hline & Autologous DC & $\begin{array}{l}\text { Therapy cycles of i.n. DC vaccination with } \\
\text { anti-PD-1 therapy, radiotherapy, GM-CSF and } \\
\text { anti-TNF-alpha therapy }\end{array}$ & Single group & Follicular lymphoma & $\|$ & 20 & NCT02677155 & Recruiting \\
\hline & DC-CIK & $\begin{array}{l}\text { Therapy cycles of i.v. DC vaccination with } \\
\text { anti-PD-1 therapy }\end{array}$ & Anti-PD-1 Ab alone & $\begin{array}{l}\text { Advanced solid } \\
\text { tumors }\end{array}$ & 1/11 & 100 & NCT03190811 & Recruiting \\
\hline & DC-CIK & $\begin{array}{l}\text { Therapy cycles of i.v. DC vaccination with } \\
\text { anti-PD-1 therapy }\end{array}$ & Anti-PD-1 Ab alone & NSCLC & |/II & 60 & NCT03360630 & Recruiting \\
\hline Anti-PD-1 Ab & DC-CIK & i.v. anti-PD-1 Ab-treated DC vaccination & Single group & $\begin{array}{l}\text { Refractory solid } \\
\text { tumors }\end{array}$ & $1 / 11$ & 50 & NCT02886897 & Recruiting \\
\hline Anti-PD-1 Ab (CT-011) & DC/tumor cell fusion vaccine & $\begin{array}{l}\text { Therapy cycles of anti-PD- } 1 \text { therapy with DC } \\
\text { vaccination post-auto-SCT }\end{array}$ & Anti-PD-1 Ab alone & Multiple myeloma & $\|$ & 35 & NCT01067287 & $\begin{array}{l}\text { Active, not } \\
\text { recruiting }\end{array}$ \\
\hline SoC CPI therapy & Autologous TLPLDC vaccine & $\begin{array}{l}\text { DC vaccination (tumor lysate }+ \text { yeast cell wall } \\
\text { particles }+\mathrm{DC} \text { ) following } \mathrm{CPI} \text { monotherapy } \\
\text { (comparison based on response to CPI therapy) }\end{array}$ & $\begin{array}{l}\text { CPI non-responder, progressive } \\
\text { disease following initial response } \\
\text { to } \mathrm{CPI} \text {, stable disease after } \mathrm{CPI}\end{array}$ & Metastatic melanoma & $|/| \mid$ & 45 & NCT02678741 & Recruiting \\
\hline $\begin{array}{l}\text { Anti-PD-L1 Ab } \\
\text { (avelumab) }\end{array}$ & Autologous DC vaccine & $\begin{array}{l}\text { Therapy cycles of DC vaccination with } \\
\text { anti-PD-L1 therapy }\end{array}$ & Single group & $\begin{array}{l}\text { Metastatic colorectal } \\
\text { cancer }\end{array}$ & |/II & 33 & NCT03152565 & $\begin{array}{l}\text { Not yet } \\
\text { recruiting }\end{array}$ \\
\hline $\begin{array}{l}\text { Anti-PD-L1 Ab } \\
\text { (durvalumab) }\end{array}$ & DC/AML fusion vaccine & Not specified & DC therapy alone, traditional care & $\begin{array}{l}\text { Acute myeloid } \\
\text { leukemia }\end{array}$ & $\|$ & 105 & NCT03059485 & Recruiting \\
\hline $\begin{array}{l}P D-L \text { siRNA lipofection } \\
\text { of the DC vaccine }\end{array}$ & MiHa-loaded DC & Post-allo-HSCT & Single group & $\begin{array}{l}\text { Hematological } \\
\text { malignancies }\end{array}$ & |/II & 10 & NCT02528682 & Recruiting \\
\hline
\end{tabular}

AML, acute myeloid leukemia; CPI, checkpoint inhibitor therapy; CIK, cytokine-induced killer cells; DC, dendritic cell; HSCT, hematopoietic stem cell transplantation; IL-2, interleukin 2; i.d., intradermal; i.n., intranodal; i.t., intratumoral; i.v., intravenous; MiHa, minor histocompatibility antigens; NSCLC, non-small-cell lung cancer; PBMC, peripheral blood mononuclear cells; PD-1, programmed death-1; PD-L1, programmed death ligand 1; siRNA, small interfering RNA; SoC, standard of care; TCR, T cell receptor; TLPLDC, tumor lysate particle-loaded dendritic cell.

Comparator(s)

Condition

Phase $\quad \boldsymbol{N}$ Trial identifier Status 
demonstrated increased expression of activation markers on DC in mice treated with sPD-1. Kuipers et al. (102), however, demonstrated a decrease in the expression of maturation markers on DCs treated with sPD-1. These discrepancies might be ascribed to different experimental settings such as the use of other sPD-1 encoding vectors. Applying the sPD-1 approach in human moDCs, Pen et al. (127) transfected mRNA encoding for sPD-1 or sPD-L1 in DC for transient local expression, thereby limiting possible adverse effects seen with systemic PD-1/PD-L blockade. With this approach, they demonstrated an upregulation of CD80 on sPD-1- or sPD-L1-expressing DCs and an increase in both $\mathrm{CD}^{+}$and $\mathrm{CD}^{+} \mathrm{T}$ cell effector functions without influencing the induction of Treg cells. Today, clinical trials evaluating this approach have not been registered.

\section{Chemo-Immunotherapy}

Anticancer chemotherapeutics remain an important systemic treatment modality to arrest or eliminate rapidly growing cancer cells. Besides lowering the tumor burden, evidence is growing that these cytotoxic drugs also rely on several off-target immunological effects, including enhancement of the immunogenicity of malignant cells and, at least for some chemotherapeutics, suppression of inhibitory mechanisms $(128,129)$. Complementing conventional chemotherapy regimens with DC-targeted immunotherapy is therefore a promising strategy, actively investigated in clinical trials for a range of malignancies ( $>140$ registered trials at Clinicaltrials.gov based on "DC and chemo" search). DC vaccine efficacy can avail from chemotherapy-induced immunogenic tumor cell death that facilitates an adaptive immune response specific for dead cell-derived antigens (130). In the context of immune checkpoint inhibition, the clinically established class of platinum-based chemotherapeutics has been designated to act via the PD-1 signaling pathway. In addition to DNA-interfering properties, oxaliplatin, cisplatin, and carboplatin were shown to inhibit the STAT6-pathway that is responsible for the upregulation of PD-1 ligands, leading to downregulation of PD-L1 and PD-L2 on both moDCs and tumor cells (131). The combination of platinum-based chemotherapeutics and DCs boosted in vitro $\mathrm{T}$ cell proliferation and enhanced $\mathrm{T}$ cell IFN- $\gamma$ and IL- 2 production (131). In other studies, however, platinum-based chemotherapeutics were reported to promote
PD-L expression on blood DC subsets (132) and tumor cells (133). Enhanced PD-L expression on DCs resulted in impaired $\mathrm{T}$ cell activation, rationalizing that the chemotherapy effect likely depends on environmental cues, such as TLR expression on those DC subsets (132). In hepatocarcinoma cells, cisplatin promoted PD-L1 overexpression both in vitro and in vivo, suggesting a mechanism of chemotherapy resistance eventually leading to a suboptimal clinical effect of cisplatin treatment (133). The contradictory outcomes of these studies highlight the need for further research on the effect of platinum-based chemotherapeutics on the functionality of different immune cells, as well as on tumor cells of various origins. In addition, it will be interesting to extend research to the clinic to determine the optimal treatment schedule where chemotherapy and DC vaccination are combined. Such combination therapies are listed in Table 2. Although these studies are not yet completed, a pilot study on the immunogenicity of DC vaccination during adjuvant platinum-based chemotherapy in colon cancer patients demonstrated enhanced antigen-specific $\mathrm{T}$ cell responses after combinatorial treatment (134).

\section{DC-Targeted PD-L RNA Interference (RNAi) Technology}

Taking into account the orchestrating role of DCs, targeted downregulation of PD-L expression on DCs is expected to potentiate DC-mediated T cell and NK cell activation and prevent Treg cell stimulation. RNAi approaches targeting immunosuppressive factors in DCs have been applied to improve immunogenic functions of next-generation DC vaccines (13). This strategy aims at enhancing DC-mediated antigen-targeted $\mathrm{T}$ cell responses at the level of the DC/effector cell immunological synapse, irrespective of tumor PD-L expression. Analogous to DCs expressing sPD-1 or SPD-L1 (vide supra), this technique offers attractive safety considerations compared to systemic antibody administration. The targeted nature of this approach shifts the in situ balance between immune stimulatory and inhibitory signals in the DC/effector cell immunological synapse toward immune stimulation, which has been suggested to result in reversal of the PD-1-mediated T cell exhaustion status (135).

Various preclinical studies demonstrated feasibility and effectivity of introducing small interfering RNAs or short hairpin

TABLE 2 | Clinical trials combining DC vaccination strategies with PD-1-/PD-L1-modulating chemotherapeutics (clinicaltrials.gov, January 14, 2018).

\begin{tabular}{ll}
\hline DC-based therapy & $\begin{array}{l}\text { PD-1-/PD-L-modulating Indication } \\
\text { chemotherapy }\end{array}$
\end{tabular}

chemotherapy

Autologous DC loaded with TAA-coding C Cisplatin Melanoma (NCT02285413), malignant pleural mesothelioma (NCT02649829)

RNA(s)

Autologous DC loaded with tumor lysate $\quad$ Multiple myeloma (NCT00083538), ovarian cancer (NCT02432378)

Autologous DC-CIK

DC-CTL Esophageal cancer (NCT01691625, NCT02644863), NSCLC (NCT02651441) NSCLC (NCT02766348)

$\begin{array}{ll}\text { Autologous DC loaded with TAA(s) } & \text { Oxaliplatin (as part of } \\ \text { Autologous DC-CIK } & \text { FOLFIRINOX) }\end{array}$ $\begin{array}{lll}\text { Autologous DC-CIK } & \text { FOLFIRINOX) } & \text { Gastric cancer (NCTO2504229, NCTO2215837), colorectal cancer (NCTO2202928, } \\ \text { NCT02415699) }\end{array}$

Autologous DC Carboplatin NSCLC (NCT02669719), breast cancer (NCT03387553)

CIK, cytokine-induced killer cell; DC, dendritic cell; DC-CTL, dendritic cytotoxic lymphocyte; NSCLC, non-small-cell lung cancer; TAA, tumor-associated antigen. 
RNAs interfering with inhibitory immune-related pathways in DCs, such as suppressor of cytokine signaling (136), indoleamine 2,3-dioxygenase (137), and PD-L1/PD-L2 (138-142). Focusing on the PD-1/PD-L pathway, silencing of PD-L1 and/or PD-L2 in DCs has been evaluated with different RNAi introduction techniques, including viral transduction and non-integrating electrotransfection, lipid nanoparticle transfection, and the cGMP-compliant transfection reagent SAINT-RED (77, 138, 141, 143, 144). Preclinical data demonstrated that PD-L-silenced DCs could (1) increase expansion, promote pro-inflammatory cytokine secretion and degranulation, and augment antitumor function of antigen-specific $\mathrm{CD}^{+} \mathrm{T}$ cells in human in vitro models $(138,140,142)$ and (2) induce significant antitumor immunity in vivo in different malignant mouse models (139, 141). Alternatively, in situ PD-L silencing can also be achieved through the use of small molecules. Dorsomorphin, a small molecule inhibitor of the bone morphogenic protein signaling pathway, was shown to efficiently downregulate PD-L1 and PD-L2 expressions on treated DCs resulting in increased $\mathrm{T}$ cell proliferation and enhanced NK cell-mediated killing of target cells (145).

Today, few DC-associated RNAi approaches are currently being tested in early-phase clinical trials, including one trial evaluating PD-L1/2-silenced DC vaccines (NCT02528682). Results of this trial are awaited.

\section{CLINICAL TRIALS}

Based on the general appreciation that DC vaccination can be improved by blockade of the PD-1/PD-L pathway, as shown by both in vitro experiments and in vivo animal models, most of these combination approaches are embedded in various clinical trials (146). With the exception of sPD-1, autologous DC vaccines are combined with (i) systemic mABs targeting PD-1 or PD-L1, (ii) platinum-based chemotherapeutics, and (iii) in situ PD-L RNAi to treat patients with both hematological cancers [multiple myeloma, acute myeloid leukemia (AML)] and solid tumors (renal cell carcinoma, mesothelioma, lymphoma, colon cancer, melanoma, ovarian cancer, pancreatic cancer, nasopharyngeal cancer, and glioblastoma). Clinical trials combining DC vaccination with PD-1/PD-L interference, registered by January 2018, are listed in Tables $\mathbf{1}$ and $\mathbf{2}$ and discussed in the corresponding paragraphs. The fast-growing number of clinical studies combining DC-based therapy with PD-1/PD-L blockade strategies emphasizes the potential of this combinatorial approach in the future treatment of cancer patients.

\section{FUTURE PERSPECTIVES}

Multimodality strategies striving to maximize the efficacy of DC-based cancer immunotherapy are emerging (16, 20, 107). Evidenced by a growing body of preclinical and clinical data, engineering next-generation DC vaccines and redirecting the tumor microenvironment are highly promising (7). The significant role of PD-1-signaling in DC-mediated antitumor immunity rationalizes its therapeutic combinatorial use in the rapidly evolving cancer immunotherapy landscape. The
PD-1-/PD-L-blocking industry-and the immune checkpoint industry in general-has expanded drastically in the last years. Leading pharmaceutical companies are putting huge efforts in the development of systemic antibody therapies, with an estimated market value of $\$ 35$ billion (147). The market for DC-based therapies is as big, with approximately 500 clinical trials registered evaluating DC vaccines, reflecting the immense scientific and pharmaceutical impact of such combinatorial therapy. The growing understanding of the immunological effects of some conventional chemotherapeutics, related to DC activation and PD-1 therapy sensitivity and resistance, provides rationale for the development of synergistic adjuvant combinations and carefully designed chemoimmunotherapy schedules that aim beyond the mere elimination of the suppressive tumor $(20,107)$. In addition to the pioneering CTLA-4 and PD-1 inhibitors, other immune checkpoints have been attributed to hamper DC-mediated immunity, including LAG-3 and TIM-3 $(56,119,148)$. The LAG-3 mAB IMP321 was demonstrated to induce DC maturation (149-151) and is now further tested in clinical trials (NCT00351949, NCT00349934). TIM-3, present on, among others, DCs, was shown to induce T helper 1 cell death when interacting with its ligand galectin-9 on T cells (119, 152), whereas dual blockade of TIM-3 and PD-1 or CTLA-4 was able to suppress tumor growth with possibility of cure in a fibrosarcoma mouse model (153). Overall, targeting multiple immune checkpoints simultaneously with DC therapy is likely to result in synergistic efficacy (107).

Designed to potentiate the patient's own immune system, unsatisfactory DC-based therapy efficacy led to an era of meticulous vaccine and protocol optimization aiming to enhance vaccine immunogenicity $(7,20)$. With the approval of immune checkpoint inhibitors, the significance of simultaneously targeting the inhibitory immune mechanisms was clinically established. In search of a balanced treatment, combinatorial DC and PD-1 pathway-targeted immunotherapy has some implications. The lack of specificity of systemic immune checkpoint blockade is prone to eliciting indiscriminate immune activation, resulting in significant immune-mediated adverse reactions and immune-related adverse events. In addition to the frequently observed development of therapy resistance, vigilant immunomonitoring to elucidate these mechanisms and advance early detection is warranted $(105,154,155)$. Recently, resistance to anti-PD-1 therapy has been related to disturbance of antigen presentation, DC migration, and DC maturation (156), underscoring the importance of combinatorial treatment schedules. More than 20 years of clinical testing affirms that tumor-specific DC therapy is well tolerated and safe, and overstimulation, autoimmunity, or therapy resistance has been described $(11,20)$. By robustly breaching PD-1-related inhibitory signaling and demasking immune evasion, DC therapy could get that extra push to prevail durable antitumor immunity while compensating for the lack of specificity of immune checkpoint blockade (107).

Taken apart, it can be concluded that DC therapy and PD-1 blocking approaches will prove best in a combinatorial setting subject to the malignancy and the disease status (157). In this perspective, the search for biomarkers predicting response 
to DC therapy and to PD-1 pathway blockade is imperative $(20,155,158)$. Although immune checkpoint inhibition can be strikingly effective in immunogenic cancers with high mutational burden like melanoma and lung cancer, tumors with a lower number of mutations and lower immunogenicity may be inherently resistant to this form of therapy $(154,155)$. Complementary, DC efficacy is high for at least some tumors with low mutational burden, like leukemia (159-162) and glioblastoma (20), further emphasizing the combinatorial use of DC vaccination with $\mathrm{PD}$-1-targeted strategies to improve DC performance. Exemplifying a combinatorial approach with AML, DC vaccinations are typically administered as a consolidation therapy after conventional chemotherapy, to prevent relapse by eliminating residual leukemic cells and by generating durable antileukemic immunity $(159,161,163)$. A role for PD-1 after conventional leukemia therapy has been demonstrated, supported by chemotherapy-induced upregulation of PD-1 on T cells and increased T cell PD-1 expression at relapse after hematopoietic stem cell transplantation $(47,164)$. Therapeutically, PD-1 checkpoint blockade in AML has been suggested to relieve Treg-mediated immunosuppression (47). Empowering adjuvant DC vaccination by blocking the inhibitory PD-1 axis could alleviate DC-mediated adaptive and innate antitumor immune responses, reflecting a promising combination as a follow-up therapy.

\section{CONCLUSION}

In this review, we highlighted the role of the $\mathrm{PD}-1$ pathway in DC-mediated antitumor immunity. Aiming to improve DC therapy efficacy, different strategies to invigorate DC immunopotency by impeding PD-1-mediated immune regulation were discussed.

\section{REFERENCES}

1. O'Keeffe M, Mok WH, Radford KJ. Human dendritic cell subsets and function in health and disease. Cell Mol Life Sci (2015) 72(22):4309-25. doi:10.1007/ s00018-015-2005-0

2. Lion E, Smits EL, Berneman ZN, Van Tendeloo VF. NK cells: key to success of DC-based cancer vaccines? Oncologist (2012) 17(10):1256-70. doi:10.1634/ theoncologist.2011-0122

3. Van Acker HH, Anguille S, Van Tendeloo VF, Lion E. Empowering gamma delta T cells with antitumor immunity by dendritic cell-based immunotherapy. Oncoimmunology (2015) 4(8):e1021538. doi:10.1080/2162402x.2015.1021538

4. Sabado RL, Bhardwaj N. Directing dendritic cell immunotherapy towards successful cancer treatment. Immunotherapy (2010) 2(1):37-56. doi:10.2217/ imt.09.43

5. Rolinski J, Hus I. Breaking immunotolerance of tumors: a new perspective for dendritic cell therapy. J Immunotoxicol (2014) 11(4):311-8. doi:10.3109/ 1547691x.2013.865094

6. Thordardottir S, Hangalapura BN, Hutten T, Cossu M, Spanholtz J, Schaap N, et al. The aryl hydrocarbon receptor antagonist StemRegenin 1 promotes human plasmacytoid and myeloid dendritic cell development from CD34+ hematopoietic progenitor cells. Stem Cells Dev (2014) 23(9):955-67. doi:10.1089/ scd.2013.0521

7. Anguille S, Smits EL, Bryant C, Van Acker HH, Goossens H, Lion E, et al. Dendritic cells as pharmacological tools for cancer immunotherapy. Pharmacol Rev (2015) 67(4):731-53. doi:10.1124/pr.114.009456

8. Bracci L, Capone I, Moschella F, Proietti E, Belardelli F. Exploiting dendritic cells in the development of cancer vaccines. Expert Rev Vaccines (2013) 12(10):1195-210. doi:10.1586/14760584.2013.836905
From the most advanced research on therapeutic blocking antibodies, lessons learned from chemotherapy-induced immune regulation, and data from more recent developments with genesilencing techniques, it can be concluded that combinatorial DC and PD-1 pathway-targeted therapy approaches could complement or even synergize under defined circumstances. Five years after the comprehensive review on combination therapy with DC vaccines and immune checkpoint blockade by Vasaturo et al. (107), touching upon the first few preclinical studies on PD-1 combination strategies in particular, we witness that preclinical research has expanded drastically and has been translated into a number of clinical trials. We are now awaiting the first clinical results that will substantially direct future anticancer treatment approaches.

\section{AUTHOR CONTRIBUTIONS}

MV, JVDB, EM, and EL wrote the paper. ES, VVT, and WH critically revised the manuscript.

\section{FUNDING}

This work has been performed with support of the University of Antwerp (Special Research Fund, BOF-KP Project-ID 32809), Stichting tegen Kanker (Belgian Foundation against Cancer; grant number 2014-155), and Kom op tegen Kanker (Stand up to Cancer-the Flemish Cancer Society). MV is funded by an SB-fellowship from the Research Foundation-Flanders (FWO; grant number $1 \mathrm{~S} 24517 \mathrm{~N}$ ). JVDB was funded by an Emmanuel van der Schueren fellowship from Kom op tegen Kanker. EM is a research fellow of Flanders Innovation \& Entrepreneurship (IWT; fellowship number 141433).

9. Bol KF, Schreibelt G, Gerritsen WR, de Vries IJ, Figdor CG. Dendritic cellbased immunotherapy: state of the art and beyond. Clin Cancer Res (2016) 22(8):1897-906. doi:10.1158/1078-0432.ccr-15-1399

10. Hsu FJ, Benike C, Fagnoni F, Liles TM, Czerwinski D, Taidi B, et al. Vaccination of patients with B-cell lymphoma using autologous antigen-pulsed dendritic cells. Nat Med (1996) 2(1):52-8. doi:10.1038/nm0196-52

11. Anguille S, Smits EL, Lion E, van Tendeloo VF, Berneman ZN. Clinical use of dendritic cells for cancer therapy. Lancet Oncol (2014) 15(7):e257-67. doi:10.1016/s1470-2045(13)70585-0

12. Boudreau JE, Bonehill A, Thielemans K, Wan Y. Engineering dendritic cells to enhance cancer immunotherapy. Mol Ther (2011) 19(5):841-53. doi:10.1038/ mt.2011.57

13. Sioud M. Engineering better immunotherapies via RNA interference. Hum Vaccin Immunother (2014) 10(11):3165-74. doi:10.4161/hv.29754

14. Ilett EJ, Prestwich RJD, Melcher AA. The evolving role of dendritic cells in cancer therapy. Expert Opin Biol Ther (2010) 10(3):369-79. doi:10.1517/ 14712590903559830

15. Turnis ME, Rooney CM. Enhancement of dendritic cells as vaccines for cancer. Immunotherapy (2010) 2(6):847-62. doi:10.2217/imt.10.56

16. Datta J, Berk E, Cintolo JA, Xu S, Roses RE, Czerniecki BJ. Rationale for a multimodality strategy to enhance the efficacy of dendritic cell-based cancer immunotherapy. Front Immunol (2015) 6:271. doi:10.3389/fimmu. 2015.00271

17. Pizzurro GA, Barrio MM. Dendritic cell-based vaccine efficacy: aiming for hot spots. Front Immunol (2015) 6:91. doi:10.3389/fimmu.2015.00091

18. Vandenberk L, Belmans J, Van Woensel M, Riva M, Van Gool SW. Exploiting the immunogenic potential of cancer cells for improved dendritic cell vaccines. Front Immunol (2016) 6:663. doi:10.3389/fimmu.2015.00663 
19. Wei D, Ran W, Hongchang S, Yang N, Long M, Jiajun D. Combination of DC vaccine and conventional chemotherapeutics. Anticancer Agents Med Chem (2016) 16(5):558-67. doi:10.2174/1871520615666150907094139

20. Garg AD, Coulie PG, Van den Eynde BJ, Agostinis P. Integrating next-generation dendritic cell vaccines into the current cancer immunotherapy landscape. Trends Immunol (2017) 38(8):577-93. doi:10.1016/j.it.2017.05.006

21. Hurwitz AA, Lee S, Knox S, Kohrt H, Verdeil G, Romano E, et al. 29th Annual meeting of the Society for Immunotherapy of Cancer (SITC). J Immunother Cancer (2015) 3(1):17. doi:10.1186/s40425-015-0062-4

22. Shrimali RK, Janik JE, Abu-Eid R, Mkrtichyan M, Khleif SN. Programmed death-1 \& its ligands: promising targets for cancer immunotherapy. Immunotherapy (2015) 7(7):777-92. doi:10.2217/imt.15.49

23. Okazaki T, Honjo T. The PD-1-PD-L pathway in immunological tolerance. Trends Immunol (2006) 27(4):195-201. doi:10.1016/j.it.2006.02.001

24. Muenst S, Soysal SD, Tzankov A, Hoeller S. The PD-1/PD-L1 pathway: biological background and clinical relevance of an emerging treatment target in immunotherapy. Expert Opin Ther Targets (2015) 19(2):201-11. doi:10.1517/ 14728222.2014.980235

25. Keir ME, Butte MJ, Freeman GJ, Sharpe AH. PD-1 and its ligands in tolerance and immunity. Annu Rev Immunol (2008) 26:677-704. doi:10.1146/annurev. immunol.26.021607.090331

26. Wang J, Yoshida T, Nakaki F, Hiai H, Okazaki T, Honjo T. Establishment of NOD-Pdcd1-/- mice as an efficient animal model of type I diabetes. Proc Natl Acad Sci U S A (2005) 102(33):11823-8. doi:10.1073/pnas.0505497102

27. Guleria I, Khosroshahi A, Ansari MJ, Habicht A, Azuma M, Yagita H, et al. A critical role for the programmed death ligand 1 in fetomaternal tolerance. J Exp Med (2005) 202(2):231-7. doi:10.1084/jem.20050019

28. Ellis JS, Guloglu FB, Tartar DM, Hoeman CM, Haymaker CL, Cascio JA, et al. APCs expressing high levels of programmed death ligand 2 sustain the development of CD4 T cell memory. JImmunol (2010) 185(6):3149-57. doi:10.4049/jimmunol.1000810

29. Karunarathne DS, Horne-Debets JM, Huang JX, Faleiro R, Leow CY, Amante F, et al. Programmed death-1 ligand 2-mediated regulation of the PD-L1 to PD-1 axis is essential for establishing CD4(+) T cell immunity. Immunity (2016) 45(2):333-45. doi:10.1016/j.immuni.2016.07.017

30. Zhou Q, Xiao H, Liu Y, Peng Y, Hong Y, Yagita H, et al. Blockade of programmed death-1 pathway rescues the effector function of tumor-infiltrating $\mathrm{T}$ cells and enhances the antitumor efficacy of lentivector immunization. J Immunol (2010) 185(9):5082-92. doi:10.4049/jimmunol.1001821

31. Fourcade J, Sun Z, Pagliano O, Guillaume P, Luescher IF, Sander C, et al. CD8+ $\mathrm{T}$ cells specific for tumor antigens can be rendered dysfunctional by the tumor microenvironment through upregulation of the inhibitory receptors BTLA and PD-1. Cancer Res (2012) 72(4):887-96. doi:10.1158/0008-5472.CAN-11-2637

32. Tseng SY, Otsuji M, Gorski K, Huang X, Slansky JE, Pai SI, et al. B7-DC, a new dendritic cell molecule with potent costimulatory properties for T cells. J Exp Med (2001) 193(7):839-46. doi:10.1084/jem.193.7.839

33. Shin T, Yoshimura K, Shin T, Crafton EB, Tsuchiya $H$, Housseau F, et al. In vivo costimulatory role of B7-DC in tuning T helper cell 1 and cytotoxic T lymphocyte responses. J Exp Med (2005) 201(10):1531-41. doi:10.1084/jem.20050072

34. Nie X, Chen W, Zhu Y, Huang B, Yu W, Wu Z, et al. B7-DC (PD-L2) costimulation of CD4(+) T-helper 1 response via RGMb. Cell Mol Immunol (2017) 14:1-10. doi:10.1038/cmi.2017.17

35. Topalian SL, Drake CG, Pardoll DM. Immune checkpoint blockade: a common denominator approach to cancer therapy. Cancer Cell (2015) 27(4):450-61. doi:10.1016/j.ccell.2015.03.001

36. Hamanishi J, Mandai M, Iwasaki M, Okazaki T, Tanaka Y, Yamaguchi K, et al. Programmed cell death 1 ligand 1 and tumor-infiltrating CD8+ T lymphocytes are prognostic factors of human ovarian cancer. Proc Natl Acad Sci U S A (2007) 104(9):3360-5. doi:10.1073/pnas.0611533104

37. Thompson RH, Dong H, Lohse CM, Leibovich BC, Blute ML, Cheville JC, et al. PD-1 is expressed by tumor-infiltrating immune cells and is associated with poor outcome for patients with renal cell carcinoma. Clin Cancer Res (2007) 13(6):1757-61. doi:10.1158/1078-0432.ccr-06-2599

38. Hino R, Kabashima K, Kato Y, Yagi H, Nakamura M, Honjo T, et al. Tumor cell expression of programmed cell death- 1 ligand 1 is a prognostic factor for malignant melanoma. Cancer (2010) 116(7):1757-66. doi:10.1002/cncr.24899

39. Chen YB, Mu CY, Huang JA. Clinical significance of programmed death-1 ligand-1 expression in patients with non-small cell lung cancer: a 5-yearfollow-up study. Tumori (2012) 98(6):751-5. doi:10.1700/1217.13499
40. Wu P, Wu D, Li L, Chai Y, Huang J. PD-L1 and survival in solid tumors: a meta-analysis. PLoS One (2015) 10(6):e0131403. doi:10.1371/journal.pone. 0131403

41. Ding Y, Sun C, Li J, Hu L, Li M, Liu J, et al. The prognostic significance of soluble programmed death ligand 1 expression in cancers: a systematic review and meta-analysis. Scand J Immunol (2017) 86(5):361-7. doi:10.1111/sji.12596

42. Wang Q, Liu F, Liu L. Prognostic significance of PD-L1 in solid tumor: an updated meta-analysis. Medicine (Baltimore) (2017) 96(18):e6369. doi: $10.1097 / \mathrm{md} .0000000000006369$

43. Gadiot J, Hooijkaas AI, Kaiser AD, van Tinteren H, van Boven H, Blank C. Overall survival and PD-L1 expression in metastasized malignant melanoma. Cancer (2011) 117(10):2192-201. doi:10.1002/cncr.25747

44. Velcheti V, Schalper KA, Carvajal DE, Anagnostou VK, Syrigos KN, Sznol M, et al. Programmed death ligand-1 expression in non-small cell lung cancer. Lab Invest (2014) 94(1):107-16. doi:10.1038/labinvest.2013.130

45. Tumeh PC, Harview CL, Yearley JH, Shintaku IP, Taylor EJ, Robert L, et al. PD-1 blockade induces responses by inhibiting adaptive immune resistance. Nature (2014) 515(7528):568-71. doi:10.1038/nature13954

46. Brahmer JR, Hammers H, Lipson EJ. Nivolumab: targeting PD-1 to bolster antitumor immunity. Future Oncol (2015) 11(9):1307-26. doi:10.2217/ fon. 15.52

47. Sehgal A, Whiteside TL, Boyiadzis M. Programmed death-1 checkpoint blockade in acute myeloid leukemia. Expert Opin Biol Ther (2015) 15(8):1191-203. doi:10.1517/14712598.2015.1051028

48. Daud AI, Loo K, Pauli ML, Sanchez-Rodriguez R, Sandoval PM, Taravati K, et al. Tumor immune profiling predicts response to anti-PD-1 therapy in human melanoma. J Clin Invest (2016) 126(9):3447-52. doi:10.1172/JCI87324

49. Xu-Monette ZY, Zhang M, Li J, Young KH. PD-1/PD-L1 blockade: have we found the key to unleash the antitumor immune response? Front Immunol (2017) 8:1597. doi:10.3389/fimmu.2017.01597

50. Ribas A, Shin DS, Zaretsky J, Frederiksen J, Cornish A, Avramis E, et al. PD-1 blockade expands intratumoral memory T cells. Cancer Immunol Res (2016) 4(3):194. doi:10.1158/2326-6066.CIR-15-0210

51. Alvarez IB, Pasquinelli V, Jurado JO, Abbate E, Musella RM, de la Barrera SS, et al. Role played by the programmed death-1-programmed death ligand pathway during innate immunity against Mycobacterium tuberculosis. J Infect Dis (2010) 202(4):524-32. doi:10.1086/654932

52. Norris S, Coleman A, Kuri-Cervantes L, Bower M, Nelson M, Goodier MR. PD-1 expression on natural killer cells and CD8(+) T cells during chronic HIV-1 infection. Viral Immunol (2012) 25(4):329-32. doi:10.1089/vim.2011.0096

53. Benson DM Jr, Bakan CE, Mishra A, Hofmeister CC, Efebera Y, Becknell B, et al. The PD-1/PD-L1 axis modulates the natural killer cell versus multiple myeloma effect: a therapeutic target for CT-011, a novel monoclonal anti-PD-1 antibody. Blood (2010) 116(13):2286-94. doi:10.1182/blood-2010$02-271874$

54. Terme M, Ullrich E, Aymeric L, Meinhardt K, Desbois M, Delahaye N, et al. IL-18 induces PD-1-dependent immunosuppression in cancer. Cancer Res (2011) 71(16):5393-9. doi:10.1158/0008-5472.can-11-0993

55. Huang BY, Zhan YP, Zong WJ, Yu CJ, Li JF, Qu YM, et al. The PD-1/B7-H1 pathway modulates the natural killer cells versus mouse glioma stem cells. PLoS One (2015) 10(8):e0134715. doi:10.1371/journal.pone.0134715

56. Nguyen LT, Ohashi PS. Clinical blockade of PD1 and LAG3 - potential mechanisms of action. Nat Rev Immunol (2015) 15(1):45-56. doi:10.1038/nri3790

57. Ray A, Das DS, Song Y, Richardson P, Munshi NC, Chauhan D, et al. Targeting PD1-PDL1 immune checkpoint in plasmacytoid dendritic cell interactions with T cells, natural killer cells and multiple myeloma cells. Leukemia (2015) 29(6):1441-4. doi:10.1038/leu.2015.11

58. Liu Y, Cheng Y, Xu Y, Wang Z, Du X, Li C, et al. Increased expression of programmed cell death protein 1 on NK cells inhibits NK-cell-mediated anti-tumor function and indicates poor prognosis in digestive cancers. Oncogene (2017) 36(44):6143-53. doi:10.1038/onc.2017.209

59. Pesce S, Greppi M, Tabellini G, Rampinelli F, Parolini S, Olive D, et al. Identification of a subset of human natural killer cells expressing high levels of programmed death 1: a phenotypic and functional characterization. J Allergy Clin Immunol (2017) 139(1):335-46.e3. doi:10.1016/j.jaci.2016.04.025

60. Kamata T, Suzuki A, Mise N, Ihara F, Takami M, Makita Y, et al. Blockade of programmed death-1/programmed death ligand pathway enhances the antitumor immunity of human invariant natural killer T cells. Cancer Immunol Immunother (2016) 65(12):1477-89. doi:10.1007/s00262-016-1901-y 
61. Favreau M, Venken K, Faict S, Maes K, De Veirman K, De Bruyne E, et al. Both mucosal-associated invariant and natural killer T-cell deficiency in multiple myeloma can be countered by PD-1 inhibition. Haematologica (2017) 102(7):e266-70. doi:10.3324/haematol.2017.163758

62. Ribeiro ST, Ribot JC, Silva-Santos B. Five layers of receptor signaling in $\gamma \delta$ T-cell differentiation and activation. Front Immunol (2015) 6:15. doi:10.3389/ fimmu.2015.00015

63. Iwasaki M, Tanaka Y, Kobayashi H, Murata-Hirai K, Miyabe H, Sugie T, et al. Expression and function of PD-1 in human $\gamma \delta$ T cells that recognize phosphoantigens. Eur J Immunol (2011) 41(2):345-55. doi:10.1002/eji.201040959

64. Lopez RD, Mineishi S, Lamb LS, Kim H-G, Beck B. PD-1 (CD279) contributes to the exhaustion of gamma/delta-T cells in tumor-bearing mice. Blood (2012) 120(21):839.

65. Fleming C, Morrissey S, Cai Y, Yan J. Gamma-delta T cells: unexpected regulators of cancer development and progression. Trends Cancer (2017) 3(8):561-70. doi:10.1016/j.trecan.2017.06.003

66. FranciscoLM,SagePT,SharpeAH.ThePD-1 pathwayintoleranceandautoimmunity. Immunol Rev (2010) 236:219-42. doi:10.1111/j.1600-065X.2010.00923.x

67. Sauer S, Bruno L, Hertweck A, Finlay D, Leleu M, Spivakov M, et al. T cell receptor signaling controls Foxp3 expression via PI3K, Akt, and mTOR. Proc Natl Acad Sci U S A (2008) 105(22):7797-802. doi:10.1073/pnas.0800928105

68. Francisco LM, Salinas VH, Brown KE, Vanguri VK, Freeman GJ, Kuchroo VK, et al. PD-L1 regulates the development, maintenance, and function of induced regulatory T cells. J Exp Med (2009) 206(13):3015-29. doi:10.1084/ jem.20090847

69. Dyck L, Wilk MM, Raverdeau M, Misiak A, Boon L, Mills KHG. Anti-PD-1 inhibits Foxp3+ Treg cell conversion and unleashes intratumoural effector $\mathrm{T}$ cells thereby enhancing the efficacy of a cancer vaccine in a mouse model. Cancer Immunol Immunother (2016) 65(12):1491-8. doi:10.1007/ s00262-016-1906-6

70. Duraiswamy J, Freeman GJ, Coukos G. Therapeutic PD-1 pathway blockade augments with other modalities of immunotherapy to prevent immune decline in ovarian cancer. Cancer Res (2013) 73(23):6900-12. doi:10.1158/0008-5472. CAN-13-1550

71. Jiang J, Wang X, An H, Yang B, Cao Z, Liu Y, et al. Mucosal-associated invariant T-cell function is modulated by programmed death-1 signaling in patients with active tuberculosis. Am J Respir Crit Care Med (2014) 190(3):329-39. doi:10.1164/rccm.201401-0106OC

72. Noy R, Pollard JW. Tumor-associated macrophages: from mechanisms to therapy. Immunity (2014) 41(1):49-61. doi:10.1016/j.immuni.2014.06.010

73. Yu G-T, Bu L-L, Huang C-F, Zhang W-F, Chen W-J, Gutkind JS, et al. PD-1 blockade attenuates immunosuppressive myeloid cells due to inhibition of CD47/SIRP $\alpha$ axis in HPV negative head and neck squamous cell carcinoma. Oncotarget (2015) 6(39):42067-80. doi:10.18632/oncotarget.5955

74. Gordon SR, Maute RL, Dulken BW, Hutter G, George BM, McCracken MN, et al. PD-1 expression by tumour-associated macrophages inhibits phagocytosis and tumour immunity. Nature (2017) 545:495. doi:10.1038/nature22396

75. Lu C, Redd PS, Lee JR, Savage N, Liu K. The expression profiles and regulation of PD-L1 in tumor-induced myeloid-derived suppressor cells. Oncoimmunology (2016) 5(12):e1247135. doi:10.1080/2162402X.2016.1247135

76. Pulko V, Liu X, Krco CJ, Harris KJ, Frigola X, Kwon ED, et al. TLR3-stimulated dendritic cells up-regulate B7-H1 expression and influence the magnitude of CD8 T cell responses to tumor vaccination. J Immunol (2009) 183(6):3634-41. doi:10.4049/jimmunol.0900974

77. Hobo W, Novobrantseva T, Fredrix H, Wong J, Milstein S, Epstein-Barash H, et al. Improving dendritic cell vaccine immunogenicity by silencing PD-1 ligands using siRNA-lipid nanoparticles combined with antigen mRNA electroporation. Cancer Immunol Immunother (2013) 62(2):285-97. doi:10.1007/ s00262-012-1334-1

78. Ritprajak P, Azuma M. Intrinsic and extrinsic control of expression of the immunoregulatory molecule PD-L1 in epithelial cells and squamous cell carcinoma. Oral Oncol (2014) 51(3):221-8. doi:10.1016/j.oraloncology.2014.11.014

79. Schreiber HA, Hulseberg PD, Lee J, Prechl J, Barta P, Szlavik N, et al. Dendritic cells in chronic mycobacterial granulomas restrict local anti-bacterial $\mathrm{T}$ cell response in a murine model. PLoS One (2010) 5(7):e11453. doi:10.1371/ journal.pone.0011453

80. Mendoza-Coronel E, Camacho-Sandoval R, Bonifaz LC, Lopez-Vidal Y. PD-L2 induction on dendritic cells exposed to Mycobacterium avium downregulates BCG-specific T cell response. Tuberculosis (Edinb) (2011) 91(1):36-46. doi:10.1016/j.tube.2010.11.008

81. Sakhno LV, Tikhonova MA, Tyrinova TV, Leplina OY, Shevela EY, Nikonov SD, et al. Cytotoxic activity of dendritic cells as a possible mechanism of negative regulation of T lymphocytes in pulmonary tuberculosis. Clin Dev Immunol (2012) 2012:628635. doi:10.1155/2012/628635

82. Dai B, Xiao L, Bryson PD, Fang J, Wang P. PD-1/PD-L1 blockade can enhance HIV-1 Gag-specific T cell immunity elicited by dendritic cell-directed lentiviral vaccines. Mol Ther (2012) 20(9):1800-9. doi:10.1038/mt.2012.98

83. Curiel TJ, Wei S, Dong H, Alvarez X, Cheng P, Mottram P, et al. Blockade of B7-H1 improves myeloid dendritic cell-mediated antitumor immunity. Nat Med (2003) 9(5):562-7. doi:10.1038/nm863

84. Ge W, Ma X, Li X, Wang Y, Li C, Meng H, et al. B7-H1 up-regulation on dendritic-like leukemia cells suppresses $\mathrm{T}$ cell immune function through modulation of IL-10/IL-12 production and generation of Treg cells. Leuk Res (2009) 33(7):948-57. doi:10.1016/j.leukres.2009.01.007

85. Schneider T, Hoffmann H, Dienemann H, Schnabel PA, Enk AH, Ring S, et al. Non-small cell lung cancer induces an immunosuppressive phenotype of dendritic cells in tumor microenvironment by upregulating B7-H3. J Thorac Oncol (2011) 6(7):1162-8. doi:10.1097/JTO.0b013e31821c421d

86. Gibbons RM, Liu X, Harrington SM, Krco CJ, Kwon ED, Dong H. B7-H1 signaling is integrated during CD8(+) T cell priming and restrains effector differentiation. Cancer Immunol Immunother (2014) 63(8):859-67. doi:10.1007/ s00262-014-1563-6

87. Song S, Yuan P, Wu H, Chen J, Fu J, Li P, et al. Dendritic cells with an increased PD-L1 by TGF-beta induce T cell anergy for the cytotoxicity of hepatocellular carcinoma cells. Int Immunopharmacol (2014) 20(1):117-23. doi:10.1016/j. intimp.2014.02.027

88. Sponaas AM, Moharrami NN, Feyzi E, Standal T, Holth Rustad E, Waage A, et al. PDL1 expression on plasma and dendritic cells in myeloma bone marrow suggests benefit of targeted anti PD1-PDL1 therapy. PLoS One (2015) 10(10):e0139867. doi:10.1371/journal.pone.0139867

89. Krempski J, Karyampudi L, Behrens MD, Erskine CL, Hartmann L, Dong H, et al. Tumor-infiltrating programmed death receptor-1+ dendritic cells mediate immune suppression in ovarian cancer. J Immunol (2011) 186(12):6905-13. doi:10.4049/jimmunol.1100274

90. Lim TS, Chew V, Sieow JL, Goh S, Yeong JP, Soon AL, et al. PD-1 expression on dendritic cells suppresses CD8(+) T cell function and antitumor immunity. Oncoimmunology (2016) 5(3):e1085146. doi:10.1080/2162402x.2015.1085146

91. Ni XY, Sui HX, Liu Y, Ke SZ, Wang YN, Gao FG. TGF-beta of lung cancer microenvironment upregulates B7H1 and GITRL expression in dendritic cells and is associated with regulatory T cell generation. Oncol Rep (2012) 28(2):615-21. doi:10.3892/or.2012.1822

92. Wang L, Pino-Lagos K, de Vries VC, Guleria I, Sayegh MH, Noelle RJ. Programmed death 1 ligand signaling regulates the generation of adaptive Foxp3+CD4+ regulatory T cells. Proc Natl Acad Sci U S A (2008) 105(27): 9331-6. doi:10.1073/pnas.0710441105

93. Giuliani M, Janji B, Berchem G. Activation of NK cells and disruption of PD-L1/PD-1 axis: two different ways for lenalidomide to block myeloma progression. Oncotarget (2017) 8(14):24031-44. doi:10.18632/oncotarget.15234

94. Iraolagoitia XLR, Spallanzani RG, Torres NI, Araya RE, Ziblat A, Domaica CI, et al. NK cells restrain spontaneous antitumor CD8+ T cell priming through PD-1/PD-L1 interactions with dendritic cells. J Immunol (2016) 197(3):953. doi:10.4049/jimmunol.1502291

95. Reschner A, Hubert P, Delvenne P, Boniver J, Jacobs N. Innate lymphocyte and dendritic cell cross-talk: a key factor in the regulation of the immune response. ClinExpImmunol(2008) 152(2):219-26.doi:10.1111/j.1365-2249.2008.03624.x

96. Ostrand-Rosenberg S, Sinha P, Beury DW, Clements VK. Cross-talk between myeloid-derived suppressor cells (MDSC), macrophages, and dendritic cells enhances tumor-induced immune suppression. Semin Cancer Biol (2012) 22(4):275-81. doi:10.1016/j.semcancer.2012.01.011

97. van Beek JJP, Wimmers F, Hato SV, de Vries IJM, Skold AE. Dendritic cell cross talk with innate and innate-like effector cells in antitumor immunity: implications for DC vaccination. Crit Rev Immunol (2014) 34(6):517-36. doi:10.1615/CritRevImmunol.2014012204

98. Zhang C, Wang S, Yang C, Rong R. The crosstalk between myeloid derived suppressor cells and immune cells: to establish immune tolerance in transplantation. J Immunol Res (2016) 2016:4986797. doi:10.1155/2016/4986797 
99. Keller CW, Freigang S, Lünemann JD. Reciprocal crosstalk between dendritic cells and natural killer T cells: mechanisms and therapeutic potential. Front Immunol (2017) 8:570. doi:10.3389/fimmu.2017.00570

100. Salio M, Gasser O, Gonzalez-Lopez C, Martens A, Veerapen N, Gileadi U, et al. Activation of human mucosal-associated invariant $\mathrm{T}$ cells induces CD40L-dependent maturation of monocyte-derived and primary dendritic cells. J Immunol (2017) 199(8):2631-8. doi:10.4049/jimmunol.1700615

101. Durgan K, Ali M, Warner P, Latchman YE. Targeting NKT cells and PD-L1 pathway results in augmented anti-tumor responses in a melanoma model. Cancer Immunol Immunother (2011) 60(4):547-58. doi:10.1007/ s00262-010-0963-5

102. Kuipers H, Muskens F, Willart M, Hijdra D, van Assema FB, Coyle AJ, et al. Contribution of the PD-1 ligands/PD-1 signaling pathway to dendritic cell-mediated CD4+ T cell activation. Eur J Immunol (2006) 36(9):2472-82. doi:10.1002/eji.200635978

103. Park SJ, Namkoong H, Doh J, Choi J-C, Yang B-G, Park Y, et al. Negative role of inducible PD-1 on survival of activated dendritic cells. J Leukoc Biol (2014) 95(4):621-9. doi:10.1189/jlb.0813443

104. Herbst RS, Soria JC, Kowanetz M, Fine GD, Hamid O, Gordon MS, et al. Predictive correlates of response to the anti-PD-L1 antibody MPDL3280A in cancer patients. Nature (2014) 515(7528):563-7. doi:10.1038/nature14011

105. Alsaab HO, Sau S, Alzhrani R, Tatiparti K, Bhise K, Kashaw SK, et al. PD-1 and PD-L1 checkpoint signaling inhibition for cancer immunotherapy: mechanism, combinations, and clinical outcome. Front Pharmacol (2017) 8:561. doi:10.3389/fphar.2017.00561

106. Devaud C, John LB, Westwood JA, Darcy PK, Kershaw MH. Immune modulation of the tumor microenvironment for enhancing cancer immunotherapy. Oncoimmunology (2013) 2(8):e25961. doi:10.4161/onci.25961

107. Vasaturo A, Di Blasio S, Peeters DG, de Koning CC, de Vries JM, Figdor CG, et al. Clinical implications of co-inhibitory molecule expression in the tumor microenvironment for DC vaccination: a game of stop and go. Front Immunol (2013) 4:417. doi:10.3389/fimmu.2013.00417

108. Buchbinder EI, Desai A. CTLA- 4 and PD-1 pathways: similarities, differences, and implications of their inhibition. Am J Clin Oncol (2016) 39(1):98-106. doi:10.1097/coc.0000000000000239

109. Radford KJ, Tullett KM, Lahoud MH. Dendritic cells and cancer immunotherapy. Curr Opin Immunol (2014) 27:26-32. doi:10.1016/j.coi.2014.01.005

110. Postow MA. Managing immune checkpoint-blocking antibody side effects. Am Soc Clin Oncol Educ Book (2015) 35:76-83. doi:10.14694/EdBook_ AM.2015.35.76

111. Ochoa MC, Minute L, Rodriguez I, Garasa S, Perez-Ruiz E, Inogés S, et al. Antibody-dependent cell cytotoxicity: immunotherapy strategies enhancing effector NK cells. Immunol Cell Biol (2017) 95:347. doi:10.1038/icb.2017.6

112. Rosenblatt J, Glotzbecker B, Mills H, Vasir B, Tzachanis D, Levine JD, et al. PD-1 blockade by CT-011, anti-PD-1 antibody, enhances ex vivo T-cell responses to autologous dendritic cell/myeloma fusion vaccine.J Immunother (2011) 34(5):409-18. doi:10.1097/CJI.0b013e31821ca6ce

113. Antonios JP, Soto H, Everson RG, Orpilla J, Moughon D, Shin N, et al. PD-1 blockade enhances the vaccination-induced immune response in glioma. JCI Insight (2016) 1(10):e87059. doi:10.1172/jci.insight.87059

114. Ge Y, Xi H, Ju S, Zhang X. Blockade of PD-1/PD-L1 immune checkpoint during DC vaccination induces potent protective immunity against breast cancer in hu-SCID mice. Cancer Lett (2013) 336(2):253-9. doi:10.1016/j. canlet.2013.03.010

115. Coffelt SB, de Visser KE. Revving up dendritic cells while braking PD-L1 to jump-start the cancer-immunity cycle motor. Immunity (2016) 44(4):722-4. doi:10.1016/j.immuni.2016.03.014

116. Salmon H, Idoyaga J, Rahman A, Leboeuf M, Remark R, Jordan S, et al. Expansion and activation of $\mathrm{CD} 103(+)$ dendritic cell progenitors at the tumor site enhances tumor responses to therapeutic PD-L1 and BRAF inhibition. Immunity (2016) 44(4):924-38. doi:10.1016/j.immuni.2016.03.012

117. Hobo W, Norde WJ, Schaap N, Fredrix H, Maas F, Schellens K, et al. $\mathrm{B}$ and $\mathrm{T}$ lymphocyte attenuator mediates inhibition of tumor-reactive CD8+ $\mathrm{T}$ cells in patients after allogeneic stem cell transplantation. J Immunol (2012) 189(1):39. doi:10.4049/jimmunol.1102807

118. Stecher C, Battin C, Leitner J, Zettl M, Grabmeier-Pfistershammer K, Höller C, et al. PD-1 blockade promotes emerging checkpoint inhibitors in enhancing T cell responses to allogeneic dendritic cells. Front Immunol (2017) 8:572. doi:10.3389/fimmu.2017.00572
119. Shih K, Arkenau HT, Infante JR. Clinical impact of checkpoint inhibitors as novel cancer therapies. Drugs (2014) 74(17):1993-2013. doi:10.1007/ s40265-014-0305-6

120. Gangadhar TC, Vonderheide RH. Mitigating the toxic effects of anticancer immunotherapy. Nat Rev Clin Oncol (2014) 11(2):91-9. doi:10.1038/ nrclinonc.2013.245

121. Michot JM, Bigenwald C, Champiat S, Collins M, Carbonnel F, Postel-Vinay S, et al. Immune-related adverse events with immune checkpoint blockade: a comprehensive review. Eur J Cancer (2016) 54:139-48. doi:10.1016/j.ejca. 2015.11.016

122. Zhao P, Atanackovic D, Dong S, Yagita H, He X, Chen M. An anti-programmed death-1 antibody (alphaPD-1) fusion protein that self-assembles into a multivalent and functional alphaPD-1 nanoparticle. Mol Pharm (2017) 14(5):1494-500. doi:10.1021/acs.molpharmaceut.6b01021

123. Zhang F, Wei H, Wang X, Bai Y, Wang P, Wu J, et al. Structural basis of a novel PD-L1 nanobody for immune checkpoint blockade. Cell Discov (2017) 3:17004. doi:10.1038/celldisc.2017.4

124. Bannas P, Hambach J, Koch-Nolte F. Nanobodies and nanobody-based human heavy chain antibodies as antitumor therapeutics. Front Immunol (2017) 8:1603. doi:10.3389/fimmu.2017.01603

125. He L, Zhang G, He Y, Zhu H, Zhang HUI, Feng Z. Blockade of B7-H1 with sPD-1 improves immunity against murine hepatocarcinoma. Anticancer Res (2005) 25(5):3309-13.

126. Song M-Y, Park S-H, Nam HJ, Choi D-H, Sung Y-C. Enhancement of vaccine-induced primary and memory CD8+ T-cell responses by soluble PD-1. J Immunother (2011) 34(3):297-306. doi:10.1097/CJI.0b013e318210ed0e

127. Pen JJ, Keersmaecker BD, Heirman C, Corthals J, Liechtenstein T, Escors D, et al. Interference with PD-L1/PD-1 co-stimulation during antigen presentation enhances the multifunctionality of antigen-specific T cells. Gene Ther (2014) 21:262. doi:10.1038/gt.2013.80

128. Bracci L, Schiavoni G, Sistigu A, Belardelli F. Immune-based mechanisms of cytotoxic chemotherapy: implications for the design of novel and rationale-based combined treatments against cancer. Cell Death Differ (2014) 21(1):15-25. doi:10.1038/cdd.2013.67

129. Galluzzi L, Buque A, Kepp O, Zitvogel L, Kroemer G. Immunological effects of conventional chemotherapy and targeted anticancer agents. Cancer Cell (2015) 28(6):690-714. doi:10.1016/j.ccell.2015.10.012

130. Garg AD, More S, Rufo N, Mece O, Sassano ML, Agostinis P, et al. Trial watch: immunogenic cell death induction by anticancer chemotherapeutics. Oncoimmunology (2017) 6(12):e1386829. doi:10.1080/2162402x.2017.1386829

131. Lesterhuis WJ, Punt CJ, Hato SV, Eleveld-Trancikova D, Jansen BJ, Nierkens S, et al. Platinum-based drugs disrupt STAT6-mediated suppression of immune responses against cancer in humans and mice. J Clin Invest (2011) 121(8):3100-8. doi:10.1172/jci43656

132. Tel J, Hato SV, Torensma R, Buschow SI, Figdor CG, Lesterhuis WJ, et al. The chemotherapeutic drug oxaliplatin differentially affects blood DC function dependent on environmental cues. Cancer Immunol Immunother (2012) 61(7):1101-11. doi:10.1007/s00262-011-1189-x

133. Qin X, Liu C, Zhou Y, Wang G. Cisplatin induces programmed death-1-ligand 1(PD-L1) over-expression in hepatoma H22 cells via Erk/MAPK signaling pathway. Cell Mol Biol (Noisy-le-grand) (2010) 56(Suppl):Ol1366-72.

134. Lesterhuis WJ, de Vries IJ, Aarntzen EA, de Boer A, Scharenborg NM, van de Rakt M, et al. A pilot study on the immunogenicity of dendritic cell vaccination during adjuvant oxaliplatin/capecitabine chemotherapy in colon cancer patients. Br J Cancer (2010) 103(9):1415-21. doi:10.1038/sj. bjc. 6605935

135. Liu J, Zhang S, Hu Y, Yang Z, Li J, Liu X, et al. Targeting PD-1 and Tim-3 pathways to reverse CD8 T-cell exhaustion and enhance ex vivo T-cell responses to autologous dendritic/tumor vaccines. J Immunother (2016) 39(4):171-80. doi:10.1097/CJI.0000000000000122

136. Shen L, Evel-Kabler K, Strube R, Chen SY. Silencing of SOCS1 enhances antigen presentation by dendritic cells and antigen-specific anti-tumor immunity. Nat Biotechnol (2004) 22(12):1546-53. doi:10.1038/nbt1035

137. Zheng X, Koropatnick J, Chen D, Velenosi T, Ling H, Zhang X, et al. Silencing IDO in dendritic cells: a novel approach to enhance cancer immunotherapy in a murine breast cancer model. Int J Cancer (2013) 132(4):967-77. doi:10.1002/ijc. 27710

138. Hobo W, Maas F, Adisty N, de Witte T, Schaap N, van der Voort R, et al. siRNA silencing of PD-L1 and PD-L2 on dendritic cells augments expansion 
and function of minor histocompatibility antigen-specific CD8+ T cells. Blood (2010) 116(22):4501-11. doi:10.1182/blood-2010-04-278739

139. Karwacz K, Bricogne C, MacDonald D, Arce F, Bennett CL, Collins M, et al. PD-L1 co-stimulation contributes to ligand-induced T cell receptor down-modulation on CD8+ T cells. EMBO Mol Med (2011) 3(10):581-92. doi:10.1002/emmm.201100165

140. Wang S, Wang Y, Liu J, Shao S, Li X, Gao J, et al. Silencing B7-H1 enhances the anti-tumor effect of bladder cancer antigen-loaded dendritic cell vaccine in vitro. Onco Targets Ther (2014) 7:1389-96. doi:10.2147/ott.s65367

141. Daneshmandi S, Pourfathollah AA, Karimi MH, Emadi-Baygi M. PDL-1/ PDL-2 blockade in mice dendritic cells by RNAi techniques to induce antitumor immunity. Immunotherapy (2015) 7(11):1145-58. doi:10.2217/ imt. 15.80

142. Van den Bergh JMJ, Smits E, Berneman ZN, Hutten TJA, De Reu H, Van Tendeloo VFI, et al. Monocyte-derived dendritic cells with silenced PD-1 ligands and transpresenting interleukin-15 stimulate strong tumor-reactive T-cell expansion. Cancer Immunol Res (2017) 5(8):710-5. doi:10.1158/23266066.cir-16-0336

143. Roeven MW, Hobo W, van der Voort R, Fredrix H, Norde WJ, Teijgeler K, et al. Efficient nontoxic delivery of PD-L1 and PD-L2 siRNA into dendritic cell vaccines using the cationic lipid SAINT-18. J Immunother (2015) 38(4):145-54. doi:10.1097/cji.0000000000000071

144. van der Waart AB, Fredrix H, van der Voort R, Schaap N, Hobo W, Dolstra H. siRNA silencing of PD-1 ligands on dendritic cell vaccines boosts the expansion of minor histocompatibility antigen-specific CD8(+) T cells in NOD/ SCID/IL2Rg(null) mice. Cancer Immunol Immunother (2015) 64(5):645-54. doi:10.1007/s00262-015-1668-6

145. Martínez VG, Hidalgo L, Valencia J, Hernández-López C, Entrena A, del Amo BG, et al. Autocrine activation of canonical BMP signaling regulates PD-L1 and PD-L2 expression in human dendritic cells. Eur J Immunol (2014) 44(4):1031-8. doi:10.1002/eji.201343693

146. Garg AD, Vara PerezM,SchaafM, AgostinisP, Zitvogel L, Kroemer G, etal.Trial watch: dendritic cell-based anticancer immunotherapy. Oncoimmunology (2017) 6(7):e1328341. doi:10.1080/2162402X.2017.1328341

147. Morrow T. Immunotherapies can't keep market forces at arm's length. Manag Care (2014) 23(8):55-6.

148. Pardoll DM. The blockade of immune checkpoints in cancer immunotherapy. Nat Rev Cancer (2012) 12(4):252-64. doi:10.1038/nrc3239

149. Fougeray S, Brignone C, Triebel F. A soluble LAG-3 protein as an immunopotentiator for therapeutic vaccines: preclinical evaluation of IMP321. Vaccine (2006) 24(26):5426-33. doi:10.1016/j.vaccine.2006.03.050

150. Brignone C, Grygar C, Marcu M, Perrin G, Triebel F. IMP321 (sLAG-3), an immunopotentiator for $\mathrm{T}$ cell responses against a HBsAg antigen in healthy adults: a single blind randomised controlled phase I study. J Immune Based Ther Vaccines (2007) 5:5-5. doi:10.1186/1476-8518-5-5

151. Romano E, Michielin O, Voelter V, Laurent J, Bichat H, Stravodimou A, et al. MART-1 peptide vaccination plus IMP321 (LAG-3Ig fusion protein) in patients receiving autologous PBMCs after lymphodepletion: results of a phase I trial. J Transl Med (2014) 12:97-97. doi:10.1186/1479-5876-12-97

152. Zhu C, Anderson AC, Schubart A, Xiong H, Imitola J, Khoury SJ, et al. The Tim-3 ligand galectin-9 negatively regulates T helper type 1 immunity. Nat Immunol (2005) 6:1245. doi:10.1038/ni1271
153. Ngiow SF, Teng MW, Smyth MJ. Prospects for TIM3-targeted antitumor immunotherapy. Cancer Res (2011) 71(21):6567-71. doi:10.1158/0008-5472. can-11-1487

154. Restifo NP, Smyth MJ, Snyder A. Acquired resistance to immunotherapy and future challenges. Nat Rev Cancer (2016) 16(2):121-6. doi:10.1038/ nrc.2016.2

155. Cogdill AP, Andrews MC, Wargo JA. Hallmarks of response to immune checkpoint blockade. Br J Cancer (2017) 117(1):1-7. doi:10.1038/bjc.2017.136

156. O'Donnell JS, Long GV, Scolyer RA, Teng MW, Smyth MJ. Resistance to PD1/PDL1 checkpoint inhibition. Cancer Treat Rev (2017) 52:71-81. doi:10.1016/j.ctrv.2016.11.007

157. Kranz LM, Birtel M, Krienke C, Grunwitz C, Petschenka J, Reuter KC, et al. CIMT 2015: the right patient for the right therapy - report on the 13th annual meeting of the Association for Cancer Immunotherapy. Hum Vaccin Immunother (2016) 12(1):213-21. doi:10.1080/21645515.2015.1068485

158. Patel SP, Kurzrock R. PD-L1 expression as a predictive biomarker in cancer immunotherapy. Mol Cancer Ther (2015) 14(4):847-56. doi:10.1158/15357163.mct-14-0983

159. VanTendeloo VF, VandeVeldeA, Van Driessche A, CoolsN, AnguilleS, LadellK, et al. Induction of complete and molecular remissions in acute myeloid leukemia by Wilms' tumor 1 antigen-targeted dendritic cell vaccination. Proc Natl Acad Sci U S A (2010) 107(31):13824-9. doi:10.1073/pnas.1008051107

160. Rosenblatt J, Stone RM, Uhl L, Neuberg D, Joyce R, Levine JD, et al. Individualized vaccination of AML patients in remission is associated with induction of antileukemia immunity and prolonged remissions. Sci Transl Med (2016) 8(368):368ra171. doi:10.1126/scitranslmed.aag1298

161. Anguille S, Van de Velde AL, Smits EL, Van Tendeloo VF, Juliusson G, Cools N, et al. Dendritic cell vaccination as postremission treatment to prevent or delay relapse in acute myeloid leukemia. Blood (2017) 130(15):1713-21. doi:10.1182/blood-2017-04-780155

162. Weinstock M, Rosenblatt J, Avigan D. Dendritic cell therapies for hematologic malignancies. Mol Ther Methods Clin Dev (2017) 5:66-75. doi:10.1016/j. omtm.2017.03.004

163. Anguille S, Willemen Y, Lion E, Smits EL, Berneman ZN. Dendritic cell vaccination in acute myeloid leukemia. Cytotherapy (2012) 14(6):647-56. doi:10.3109/14653249.2012.693744

164. Schnorfeil FM, Lichtenegger FS, Emmerig K, Schlueter M, Neitz JS, Draenert R, et al. T cells are functionally not impaired in AML: increased PD-1 expression is only seen at time of relapse and correlates with a shift towards the memory T cell compartment. J Hematol Oncol (2015) 8:93. doi:10.1186/s13045-015-0189-2

Conflict of Interest Statement: The authors declare that the research was conducted in the absence of any commercial or financial relationships that could be construed as a potential conflict of interest.

Copyright $\odot 2018$ Versteven, Van den Bergh, Marcq, Smits, Van Tendeloo, Hobo and Lion. This is an open-access article distributed under the terms of the Creative Commons Attribution License (CC BY). The use, distribution or reproduction in other forums is permitted, provided the original author(s) and the copyright owner are credited and that the original publication in this journal is cited, in accordance with accepted academic practice. No use, distribution or reproduction is permitted which does not comply with these terms. 